\title{
WSPÓŁCZESNE WIZUALIZACJE DZIEDZICTWA CYRYLA I METODEGO W PRZESTRZENI SŁOWIAŃSKIEJ
}

\author{
LiLla MOROZ-GRZELAK \\ Instytut Slawistyki PAN
}

\begin{abstract}
CONTEMPORARY VISUALIZATIONS OF THE HERITAGE OF THE SAINTS CYRIL AND METHODIUS IN THE SLAVIC DOMAIN. The paper focuses on the contemporary visualizations of the brother saints Cyril and Methodius and their heritage in the countries that cultivate their cultural legacy. The presentation of the Slavic Apostles has its own tradition in painting, icons and monuments, which is shown in a historical context in some of the Slavonic countries belonging to both the Western and the Orthodox Church tradition. It points out a special role in the spread of the Cyrillo-Methodian tradition through art in Bulgaria. The country, thanks to the cult of the Thessalonica Brothers in the Middle Ages, has developed their statures as Bulgarian Apostles, and present-day Bulgaria is in a position of depositary of their heritage. Contemporary Bulgarians express the memory of Cyril and Methodius through monuments of the Cyrillic alphabet, a tendency that extends beyond the Slavic world. Consequently, it emphasizes the symbolic importance of the Slavic alphabet.
\end{abstract}

Keywords: Cyril and Methodius, monuments, Cyrillic, letter, alphabet, Slavs

Dziedzictwo świętych Cyryla i Metodego, którzy w dyskursach słowiańskich znani są jako Apostołowie Słowiańszczyzny, Święci Bracia, Bracia Sołuńscy, misjonarze słowiańscy, święci równi apostołom, pierwsi nauczyciele słowiańscy (Jarko 1991: 107) oraz Apostołowie Butgarscy, dowodzi ich trwałego miejsca w kulturach słowiańskich. W przestrzeni tego świata istotą ich spuścizny pozostaje pismo, jakie mieli dać Słowianom, umożliwiając im poznanie Ewangelii w przystępnym dla nich alfabecie.

$\mathrm{W}$ artykule, wzmiankując jedynie pewne wydarzenia związane z budzeniem się świadomości narodowej i wyznaniowej, kiedy z różnych powodów przywracano pamięć o obu świętych, ukazane zostaną współczesne odniesienia do Cyryla i Metodego w sztuce. Konieczne wydaje się przy tym przypomnienie ich roli w tradycji bułgarskiej, gdzie przyjęto 
ich pod deskrypcją terytorialną - Apostołowie Bułgarscy - która na stałe związała ich z tym krajem, jako depozytariuszem ich dziedzictwa. Rozwój kultu Braci Sołuńskich badała Ana Stojkova ukazując go od jego początków w drugiej połowie wieku IX do końca XIV stulecia (Stojkova 2008: 309-326). Badaczka stwierdziła, iż zachowane fragmenty najstarszych dokumentów mogą sugerować, że kult Konstantyna-Cyryla rozpoczął się jeszcze na Morawach, kiedy zaraz po śmierci w Rzymie został ogłoszony błogosławionym, a kanonizowany w środowisku swego brata Metodego po 872 roku, gdy ten został arcybiskupem Moraw. Jej zdaniem, wyniesienie na ołtarze Metodego mogło nastąpić po wypędzeniu jego uczniów z Moraw i ich przybyciu do Bułgarii (886). Natomiast kult oficjalny dokonał się w ramach tzw. spontanicznej kanonizacji, jaka zachodzi w Kościele prawosławnym, dzięki uczniom Metodego, którzy w Bułgarii znaleźli schronienie. Został on zatwierdzony przez panującego wówczas pierwszego władcę chrześcijańskiego Bułgarów Borysa I Michała. Ana Stojkowa zauważyła, iż w czasach pierwszego cesarstwa bułgarskiego cześć, jaką oddawano braciom nosiła znamiona kultu państwowego, co miało służyć uniezależnieniu się od Bizancjum. Wówczas jednak Cyryl i Metody byli uznawani za nauczycieli całego słowiańskiego rodu (Stojkova 2008: 312). Dopiero po roku 1018, kiedy państwo zostało podbite przez Bizancjum, w wiekach XI i XII w związku z postępującym procesem samoidentyfikacji Bułgarów, kult Cyryla i Metodego stopniowo ulegał bułgaryzacji. Tendencja ta utrzymywała się jeszcze po utworzeniu drugiego cesarstwa bułgarskiego na początku XIII stulecia, kiedy Świętych Braci jednoznacznie wiązano już z ludem i językiem bułgarskim. Zmiana warunków społeczno-politycznych na Bałkanach w wieku XIV, gdy wprowadzono nowe formy liturgiczne, doszło do wzrostu znaczenia hezychazmu i umocnienia się w stolicy państwa w Tyrnowie czci lokalnych świętych, kult Cyryla i Metodego zaczął słabnąć. Apostołowie Bułgarscy znaleźli się na peryferiach panteonu świętych. Nie mniej jednak na ziemiach bułgarskich, podobnie, jak w innych rejonach Słowiańszczyzny pozostał jednym z najbardziej eksploatowanych kultów, który w XIX wieku przybrał charakter ideologiczny (Wojtczak 2004: 259-266). Natomiast w szerszym kontekście został on podporządkowany aktualnym potrzebom politycznym i wpisywał się w rywalizację pomiędzy Kościołem Bizantyjskim a Rzymskim o pozyskanie Słowiańszczyzny. Zerwanie jedności kościelnej przypisywane na rok 1054 spowodowało, że istniejące już wcześniej różnice między Kościołem wschodnim i zachodnim nie tylko się utrwaliły, ale i pogłębiły. Zarówno prawosławie, jak i katolicyzm zaczęły tych świętych traktować odrębnie, jako postacie należące do swoich Kościołów. Ich koncepcjom zjednoczenia chrześcijaństwa mieliby patronować Święci Bracia. Prowadzić do tego miały inicjatywy warunkowane sytuacją polityczną w Cesarstwie Bizantyjskim i Państwie Kościelnym, jakie podejmowano na przestrzeni wieków przez panujących władców 
i papieży. Owocowało to najczęściej wsparciem obrządku słowiańskiego przez władców związanych z Kościołem Rzymskokatolickim (Moroz-Grzelak 2019: 332).

Przyjęcie i akceptacja dziedzictwa Cyryla i Metodego wśród ludów i narodów słowiańskich stała się czynnikiem mobilizującym je w staraniach o zachowanie własnej tożsamości, czy demonstrowania jej we wspólnocie ogólnosłowiańskiej. Proces przywracania ich pamięci w XIX wieku odzwierciedla nie tylko piśmiennictwo, stowarzyszenia przyjmujące ich za swoich patronów, ale także sztuka, która poprzez ikonografię i rzeźbę ukazywała związki swoich narodów z ich dziedzictwem. Rocznice związane z życiem i działalnością Cyryla i Metodego stały się wówczas pretekstem do uroczystych obchodów ich pamięci. Okrągłe jubileusze upamiętniające rok 863, na który datowany jest początek misji wielkomorawskiej, rok 869, kiedy w Rzymie zmarł św. Cyryl oraz rok 885, w którym na Morawach zmarł Metody, w wieku XIX zaczęto celebrować w całym słowiańskim świecie. Przy tych okazjach podkreślano niepodważalne znaczenie obu świętych dla stworzenia podwalin piśmiennictwa i kultury słowiańskiej, poprzez uczynienie staro-cerkiewno-słowiańskiego czwartym, po grece, łacinie i hebrajskim, językiem Kościoła. Zaowocowało to zakorzenieniem się chrześcijaństwa w kulturach lokalnych, a świętych uznano za pionierów inkulturacji, przyczyniających się do samopotwierdzania się danej kultury (Baniak 2002: 41). Misja morawska', przebywanie na terenach zamieszkałych przez Słowian podległych Kościołowi rzymskiemu w XIX stuleciu stały się znaczącym argumentem papiestwa, by Apostołowie Słowiańszczyzny patronowali zbliżeniu obu religii chrześcijańskich. Takie założenie realizował chorwacki biskup Josip Juraj Strossmayer (1815-1905), który koordynował przygotowania do ogólnosłowiańskiej pielgrzymki pod patronatem Braci Sołuńskich do Rzymu w 1881 roku. Peregrynacja Słowian, poprzedzająca obchody okrągłej rocznicy śmierci Metodego, miała być etapem przygotowującym wiernych do jubileuszu (Bartolini 1885: XXIII-XXIV). W rozprzestrzenianiu kultu obu braci wspierał go kanonik Franjo Rački (1828-1894), autor kilku publikacji poświęconych pismu słowiańskiemu i czasom życia i działalności świętych. Chorwaccy duchowni liczyli na przekonanie Słowian prawosławnych do idei unii kościelnej z Rzymem. Kult Cyryla i Metodego propagowany w Chorwacji przy okazji kolejnych jubileuszy związanych z kluczowymi datami z ich historii znalazł swoje przełożenie nie tylko w publikacjach, wspieraniu działalności wydawniczej autorów słowiańskiego prawosławia czy w bitych medalach pamiątkowych ku ich czci, ale także w sztuce.

1 O znaczeniu dziedzictwa Cyryla i Metodego w zachodniej Słowiańszczyźnie pisał J. Kolbuszewski, „Z dziejów tradycji cyrylometodejskiej w Słowacji." Pamiętnik Stowiański, t. XLIV (1994). 
Proces włączania się w misję ewangelizacyjną Kościoła rzymskiego, połączony z realizacją własnych celów narodowych, nie ominął również Słoweńców. Wśród nich przywracanie pamięci o Cyrylu i Metodym było wynikiem rozwijającego się poczucia własnej tożsamości, której na przeszkodzie stało silne oddziaływanie kultury niemieckiej. W procesie wiodącym do emancypacji narodu środowisko duchowieństwa katolickiego postrzegało wpływy niemieckie jako zagrożenie. Skutkowało to jawnym wyrażaniem sprzeciwu wobec protestantyzmu oraz szkół z niemieckim językiem nauczania. Patronami wyraźnego opowiedzenia się Słoweńców za katolicyzmem, podtrzymującymi ich słowiańskość, stali się właśnie Cyryl i Metody. Główną postacią, która zainicjowała ich kult był biskup Anton Martin Slomšek (180o-1862). W 1852 roku powołał on do życia Bractwo św. Cyryla i Metodego, które stawiało sobie za cel nawracanie schizmatyków (spreobrnjenje raskolnikov). Bractwo, zatwierdzone przez Piusa IX, zaczęło się wpisywać w proces działalności misyjnej Kościoła i tym samym Słoweńcy włączali się w ogólnosłowiański nurt kultu Cyryla i Metodego (Moroz-Grzelak 2016: 59-72). W Bułgarii pamięć o Świętych Braciach znalazła swe istotne miejsce w związku ze staraniami o utworzenie Cerkwi niezależnej od hierarchii greckiej oraz z troską o rozwój oświaty w języku bułgarskim (Mihajlova 2013: 142-186). Pamięć o ich znaczeniu przywracała nie tylko literatura (Paisij 1981:17), ale także pisarze ikon i fresków cerkiewnych. Jeszcze w roku 1848 w pobliżu miejscowości Oreszak w monasterze Trojańskim p.w. Zaśnięcia Matki Bożej pojawił się fresk Św. Cyryl i Metody, autorstwa Zaharija Zografa, przedstawiający obu braci trzymających rulon z alfabetem cyrylickim.

W ikonografii i na pomnikach Bracia Sołuńscy występują zwykle razem od lewej ku prawej, w kolejności młodszy Cyryl i starszy Metody. Przedstawiani są jako biskupi greccy, łacińscy i słowiańscy (Cyryl niekiedy także jako zakonnik grecki), a ich atrybutami są księgi i zwój pisma z alfabetem słowiańskim. Na freskach czy ikonach pochodzących jeszcze z XIX wieku, nie było już istotne, że odwrócona została kolejność portretowanych postaci - pisarze ikon, oddając pierwszeństwo hierarchii cerkiewnej, ukazywali ich od lewej ku prawej jako Metodego i Cyryla, zmieniając tylko trzymane przez nich atrybuty - rulon z alfabetem albo zapisane na nim wybrane fragmenty Pisma Świętego. Najistotniejszym przesłaniem obrazów było odzwierciedlenie, że obaj bracia są autorami pisma, które umożliwiło Słowianom poznawanie Ewangelii w zrozumiałym dla nich języku. Jednym z częstszych przedstawień na takich obrazach, poza literami, pozostaje zapis na trzymanej przez nich księdze pierwszego zdania z Prologu Ewangelii św. Jana - Na początku było Stowo, a Słowo było u Boga, i Bogiem było Słowo (J 1,1) - pisane w zależności od miejsca lokalizacji obrazu czy pomnika cyrylicą, łacinką lub też głagolicą. 


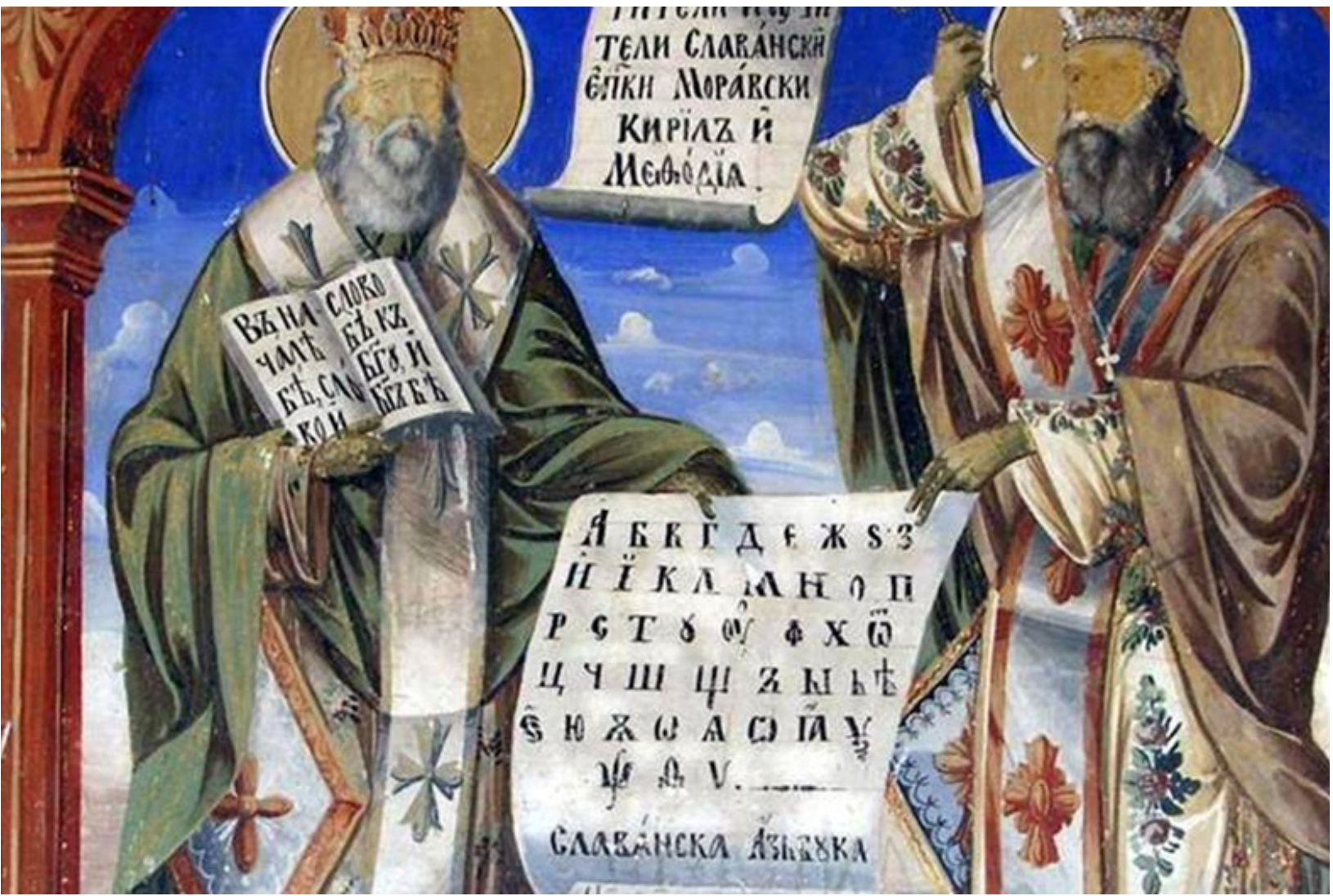

Foto 1. Fresk przedstawiający św. Metodego i Cyryla z zapisem fragmentu Ewangelii św. Jana. Źródło: https://plevenzapleven.bg/wp-content/uploads/2013/05/bratja.jpg

Również wschodnia Słowiańszczyzna przyjmowała dziedzictwo obu braci do swoich tradycji kulturowych, gdzie równi apostołom święci spełniali swą funkcję oświeceniową i tożsamościową. Na przykład w Kijowie, pod koniec roku 1845 grupa młodych intelektualistów i studentów ukraińskich powołała do istnienia działające jedynie przez 14 miesięcy Bractwo Cyryla i Metodego. Stowarzyszenie młodych ludzi przyczyniło się w efekcie do kształtowania ukraińskiego języka literackiego oraz rozwoju wielu organizacji kulturalnych. Takie działania spotkały się z represjami rządu rosyjskiego, a przywódcy Bractwa zostali skazani na zsyłkę. Symbolem wyróżniającym członków miał być pierścień z wizerunkami świętych (Golabek 1935: 287). W tym samym czasie Bracia Sołuńscy zaczęli się wpisywać w dziedzictwo historyczne Rosji, a ich kult rozpowszechniał się pod egidą władz państwowych. Wizerunki świętych znalazły się pośród 31 figur z przeszłości państwa jako Oświeciciele (Просветители) na pomniku Tysiąclecie Rosji z 1862 roku, upamiętniającego przybycie do Nowogrodu Wielkiego kniazia Ruryka, uznawanego za założyciela państwa ruskiego. Kilka lat później, w 1867 roku, Cyryl i Metody patronowali Zjazdowi Słowiańskiemu w Moskwie i Petersburgu (Krasteva 2006: 72). 
Kolejne lata niewiele zmieniły sposoby ukazywania Cyryla i Metodego w sztuce Słowian przynależnych do Kościołów prawosławnego i katolickiego. W wiekach XX i XXI, przy okazji kolejnych okrągłych jubileuszy związanych z ich działalnością, odsłaniano liczne pomniki, powstawały kościoły pod ich wezwaniem, które były najczęściej świątyniami w obrządku greko-katolickim (np. w Zagrzebiu), chociaż w Serbii zostali patronami erygowanej w 1929 roku świątyni katolickiej (Devetak 2016). W serbskim prawosławiu zajmują oni miejsce mniej znaczące, gdyż w panteonie świętych tego narodu najważniejsze pozycje zajmują postacie z historii własnego państwa średniowiecznego ze świętym Savą na czele. Jedyny monument Apostołów Słowiańszczyzny odsłonięty w Belgradzie jest kopią pomnika dłuta wybitnego rzeźbiarza macedońskiego Tome Serafimovskiego przekazaną Serbom w darze².

Ogłoszenie w 1985 roku encykliki Slavorum Apostoli Jana Pawła II, która w 1100 rocznicę śmierci Metodego czyniła Świętych Braci współpatronami Europy, obok zatwierdzonych już świętych - Benedykta z Nursji, Brygidy Szwedzkiej, Katarzyny ze Sieny i Teresy Benedykty od Krzyża. Decyzja Watykanu wywołała swoistą reakcję w prawosławnej Rosji. Ta przyjęła ją za kolejny akt aneksji (Naumow 1999: 447). W tym samym roku Plenum KP ZSRR wpisało dzień 24 maja jako Święto Piśmiennictwa i Kultury Słowiańskiej. W marcu 1989 z inicjatywy patriarchy Rosji Aleksieja II powołana została Międzynarodowa Fundacja Piśmiennictwa i Kultury Słowiańskiej (Фонд славянской письменности и культуры). Ustalono wówczas, że jej celem będzie badanie, ochrona tradycji i kultury narodów słowiańskich. Każdorazowo przy okazji uroczystości, poza kultywowaniem korzeni słowiańskiej przeszłości na organizowanych akademiach, odsłaniano kolejne pomniki Cyryla i Metodego. I tak w roku 1990, z inicjatywy pisarzy Murmańska, którym przewodził Vitalij Maslov, święto już uroczyście obchodzono. Wówczas odsłonięto tam replikę jednego z pierwszych powojennych ujęć Braci Sołuńskich, jakim jest stojący przed Bułgarską Biblioteką Narodową im. Cyryla i Metodego pomnik, zaprojektowany w roku 1963 przez Vladimira Ginovskiego, a odsłonięty w 1972 roku. Jego replika podarowana została Murmańskowi przez samych Bułgarów. 30 stycznia 1991 Prezydium Rady Najwyższej RSFSR przyjęło postanowienie o nadaniu Świętu Piśmiennictwa i Kultury Słowiańskiej statusu święta państwowo-religijnego. W 1993 roku pojawiła się też inicjatywa, podjęta przez uznanego rosyjskiego rzeźbiarza Viacheslava M. Klykova, dotycząca rozpowszechniania tzw. krzyża dziękczynnego narodów słowiańskich (Поклонный Крест славянских народов), który miał być poświęcony twórcom alfabetu słowiańskiego Cyrylowi i Metodemu. Krzyż

2 O znaczeniu Cyryla i Metodego w Macedonii pisałam w artykule „Macedońskie dziedzictwo cyrylometodejskie." Slavia Meridionalis, no 8 (2008): 327-341. 
dziękczynny, w różnych wariantach, jest multiplikowany nie tylko w miastach Rosji, ale także eksportowany poza jej granice (m.in. Grecja). Najbardziej znamiennym przykładem jego usytuowania pozostaje granica między Rosją, Ukrainą i Białorusią. Jego lokalizacja ma wskazywać i potwierdzać jedność prawosławia i Słowiańszczyzny (Поклонный 2015).

Co roku odsłaniane były kolejne pomniki z okazji obchodzonych uroczyście Dni Piśmiennictwa i Kultury Słowiańskiej. Bułgarzy uznający się za depozytariuszy schedy cyrylometodejskiej propagują ich tradycję stawiając ich monumenty zarówno w Rosji, jak i w Czechach oraz na Słowacji. Takimi był między innymi pomnik autorstwa Valentina Vasiljeva, który w 2007 roku odsłonięto w Odessie.

Innym z kolei dziełem jest pomnik autorstwa Emila Venkova odsłonięty w 2009 roku w południowych Czechach, w miejscowości Mikulčice. W tytule artykułu przypominającego o tym wydarzeniu sugeruje się, że zdaniem niewymienionego z imienia i nazwiska czeskiego archeologa, w tym właśnie mieście powinny się znajdować prochy św. Metodego (Pavlov 2019).

Także obchody kolejnej okrągłej, 1150. rocznicy rozpoczęcia misji cyrylometodejskiej, jakie przypadały w 2013 roku, były upamiętniane nie tylko w postaci uroczystych nabożeństw w ich lokalnym wymiarze, ale także na międzynarodowych konferencjach naukowych, poprzez emisje znaczków i kart pocztowych oraz w kolejnych odsłonach pomników ku czci. Następna, nowa inicjatywa uświetniania tradycji cyrylometodejskiej podjęta została na terytorium Bułgarii. 2 maja 2015 roku w pierwszej stolicy bułgarskiej, w Plisce, przy okazji uroczystych obchodów 1150 rocznicy chrztu Bułgarów, po uroczystej liturgii w starej bazylice, która uznawana jest za pierwszą prawosławną świątynię słowiańskiego świata, odsłonięto kompleks pomnikowy. Składa się on

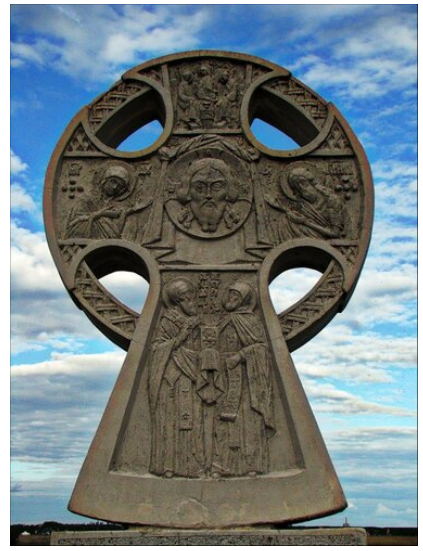

Foto 2: Krzyż dziękczynny Viacheslava Klykova.

Źródło: https://evgknyaginin. livejournal.com/72853.html

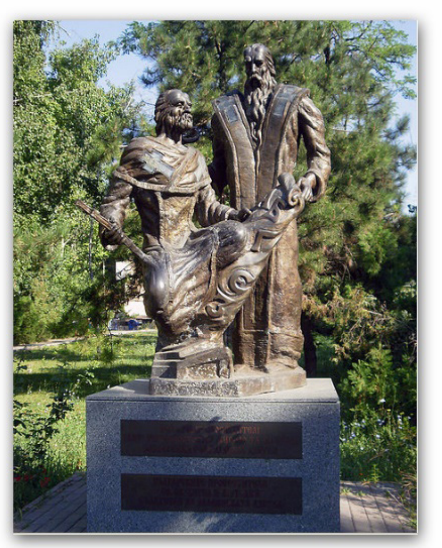

Foto 3: Pomnik autorstwa Valentina Vasiljeva w Odessie.

Źródło: https://www.pberon1926.com/view/post/872

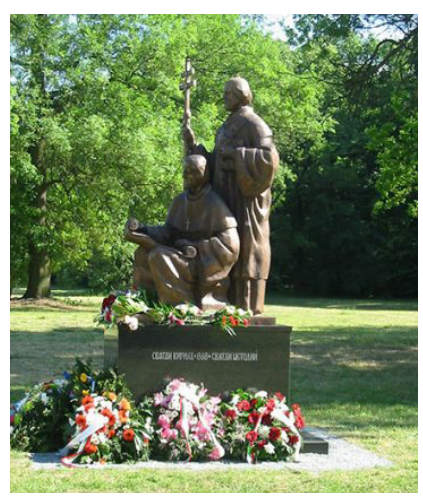

Foto 4: Czechy. Mikulčice, Emil Venkov, 2009.

Źródło: https://trud.bg/светиметодий-неизвестното-визвестн/ 
Foto 5: Autor: Behczet Danadż (Бехчет Данаджъ). Źródło: http://дворнакирилицата.bg/snimki/

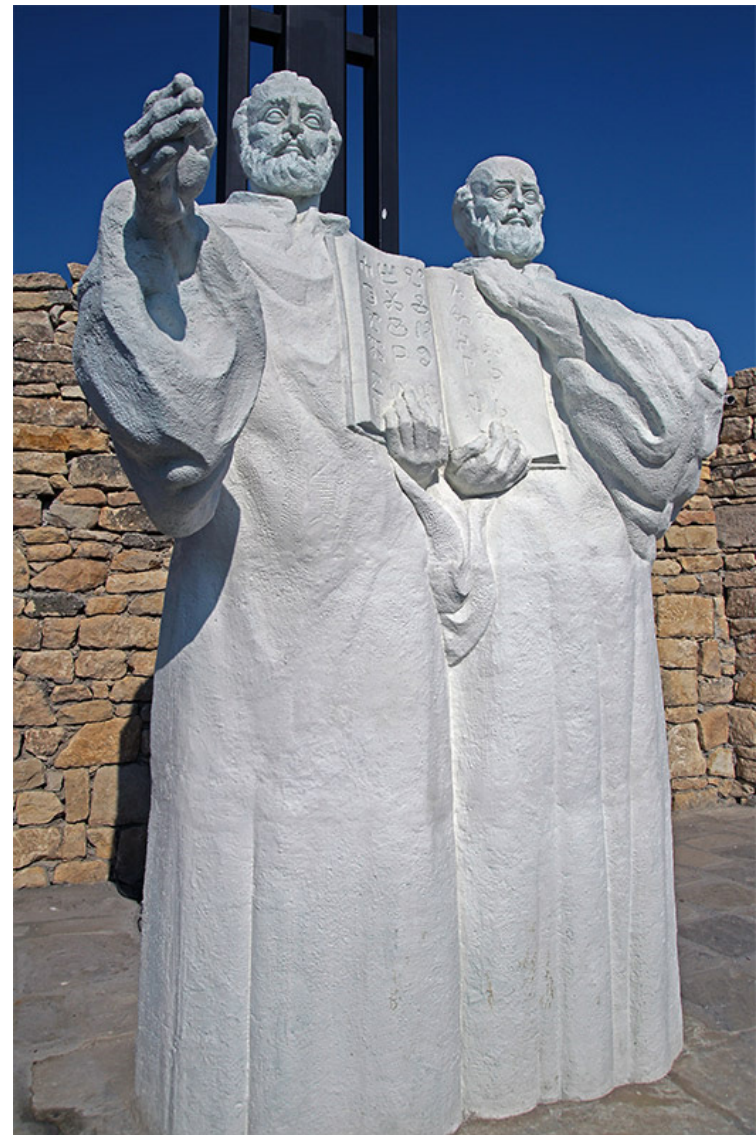

z 12 metrowego krzyża i figur Cyryla i Metodego z księgą zapisaną głagolicą, którzy według interpretacji jej autorów błogosławią nowy alfabet - cyrylicę.

Na stronie internetowej poświęconej Dziedzińcowi cyrylicy. Kompleksowi „Stara Pliska” (Двор на кирилицата. Комплекс „Стара Плиска”), jak nazywana jest ta pomnikowa inicjatywa, znajduje się informacja, że nie stworzyła go instytucja państwowa czy organizacja, ale Ormianin - Karen Aleksanjan (Карен Алексанян) - który osiadł w Bułgarii. Z własnych środków zakupił około $8000 \mathrm{~m}^{2}$ ziemi, zatrudnił budowniczych, architektów i artystów realizując swoje idee, które przedstawiane są jako hołd złożony twórcom pisma oraz tym, którzy je utrwalali. Dla niniejszego artykułu kwestią marginalną, choć wymagającą wzmianki, wydaje się być komercyjny charakter przedsięwzięcia, które wraz z infrastrukturą i jego hotelowym otoczeniem stanowi Kompleks kulturalno-historyczny i rozrywkowy „Stara Pliska” (Културно-исторически и развлекателен комплекс “Стара Плиска”). Istotne jest, że znajdujące się tam pomniki przedstawiają też wszystkie litery alfabetu cyrylickiego, z całą semantyką związaną z poszczególnymi literami, nawiązującą do symboliki najstarszych dzieł literatury bułgarskiej - Modlitwy abecadłowej, Proglasu do Ewangelii oraz O literach Czernorizca Chrabra. Ich autorem, wraz z objaśniającą je symboliką, jest ormiański rzeźbiarz Ruben Nalbandjan. (Dvor 2019). 


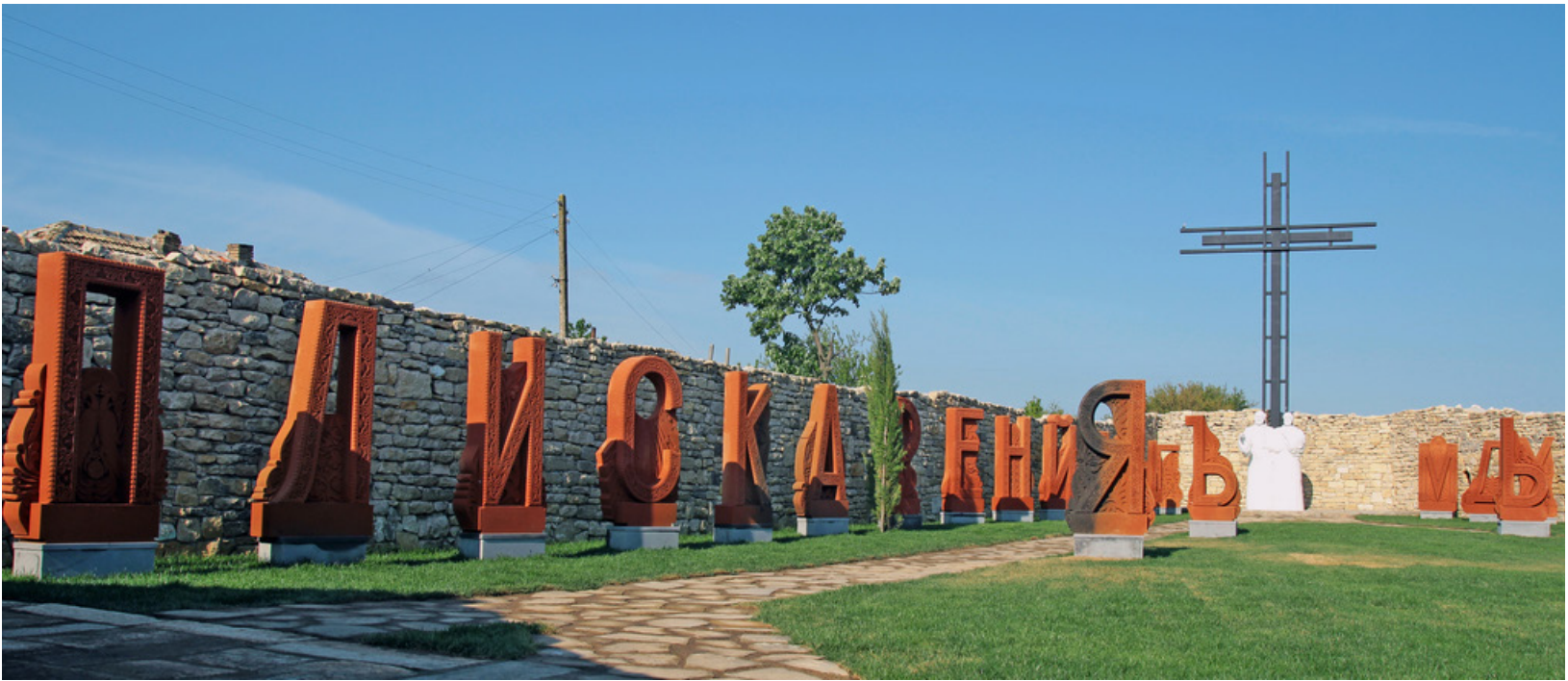

Foto 6: Pismo. Usytuowanie liter tworzy napis PLISKA. Autor: Ruben Nalbandjan.

Źródło: http://дворнакирилицата.bg/snimki/

W innej części kompleksu znajdują się popiersia pisarzy posługujących się cyrylicą, gdzie obok zasłużonych twórców bułgarskich, a wśród nich m.in. Ivana Vazowa, Hristo Boteva, Aleko Konstatntinova, odsłaniane są sukcesywnie od roku 2017 rzeźby twórców z krajów, gdzie cyrylica pozostaje oficjalnym alfabetem, m.in. z Rosji, Osetii, czy Serbii. Na dziedzińcu znajduje się również ściana z reliefami bułgarskich i obcych autorów dla dzieci, którzy swoje utwory pisali cyrylicą. Bułgarscy artyści, także poza granicami swego kraju, podejmują inicjatywy przypominające dziedzictwo Cyryla i Metodego. Rzeźbiarz Andrej Vrabchev, zainspirowany głagolicą, odwołując się do alfabetu stworzonego przez Cyryla podjął próbę stworzenia symbolicznego mostu duchowego pomiędzy Bułgarią a Słowacją, popularyzując misję braci pomiędzy narodami słowiańskimi. Potwierdzeniem istnienia więzi duchowych miała być wystawiana podczas XX Festiwalu Rzeźba i Obiekt w Bratysławie w 2015 roku, kamienna rzeźba, eksponowana później także w Wiedniu, której tytuł nawiązuje do pierwszych liter alfabetu cyrylickiego АБВ (AВW), (Vrabchev 2015).

Poza zrealizowanym pomysłem mieszkającego w Szumenie Ormianina, czy czasowymi ekspozycjami bułgarskiego twórcy, urzeczywistniane są też inne, które mają popularyzować cyrylicę i tym samym dokonania Cyryla i Metodego na całym świecie. Jednym z najgłośniejszych jest projekt Misja Bułgaria (Мисия България), którego inicjatorami są bułgarscy profesorowie - historyk Plamen Pavlov (Пламен Павлов) i archeolog Nikolaj Ovcharov (Николай Овчаров). Celem podjętej przez nich inicjatywy, wspieranej przez władze, jest promocja bułgarskiego dziedzictwa historycznego na świecie, a także demonstrowanie rangi cyrylicy. Obaj naukowcy prowadzą wspólne wykłady na temat bułgarskiego 
dziedzictwa kulturowego i historycznego w różnych częściach świata, koncentrując się na historii średniowiecznej i alfabecie swego kraju. Wypowiedzi profesora Nikolaja Ovcharova w mediach dowodzą, że w ramach rozwoju turystyki kulturalno-historycznej, projekt urzeczywistnia się (Antova: 2018). Potwierdzeniem tego było uroczyste odsłonięcie 11 maja 2015 roku przed jedną ze szkół w Ułan Bator pomnika pisma cyrylickiego. Dokonano tego przy okazji wizyty prezydenta Bułgarii (w latach 2012-2017), Rosena Asenova Plevnelieva, upamiętniającej 65. rocznicę nawiązania stosunków dyplomatycznych między dwoma krajami. Odsłaniając monument w dniu święta Cyryla i Metodego prezydent podkreślił, że naród mongolski jest jednym z 50 na świecie, który posługuje się cyrylicą, pismem stworzonym ponad 11 wieków temu przez braci z Salonik, a jego użytkownikami jest ponad 300 ooo ooo ludzi na całym świecie (Kamenov 2015). Autorka nie podejmuje w tym miejscu polemiki z danymi przytoczonymi przez bułgarskiego prezydenta dotyczącymi liczebności użytkowników cyrylicy. Istotą pozostaje fakt, że zgodnie z zamysłem inicjatorów pomysłu, jego realizacja ma potwierdzać rangę dokonań Świętych Braci, a ich znaczenie ważne jest także dla kultury Mongolii, gdyż w 1945 roku alfabet ten stał się oficjalnym systemem pisma niesłowiańskiego kraju (Dzhambazova 2013).

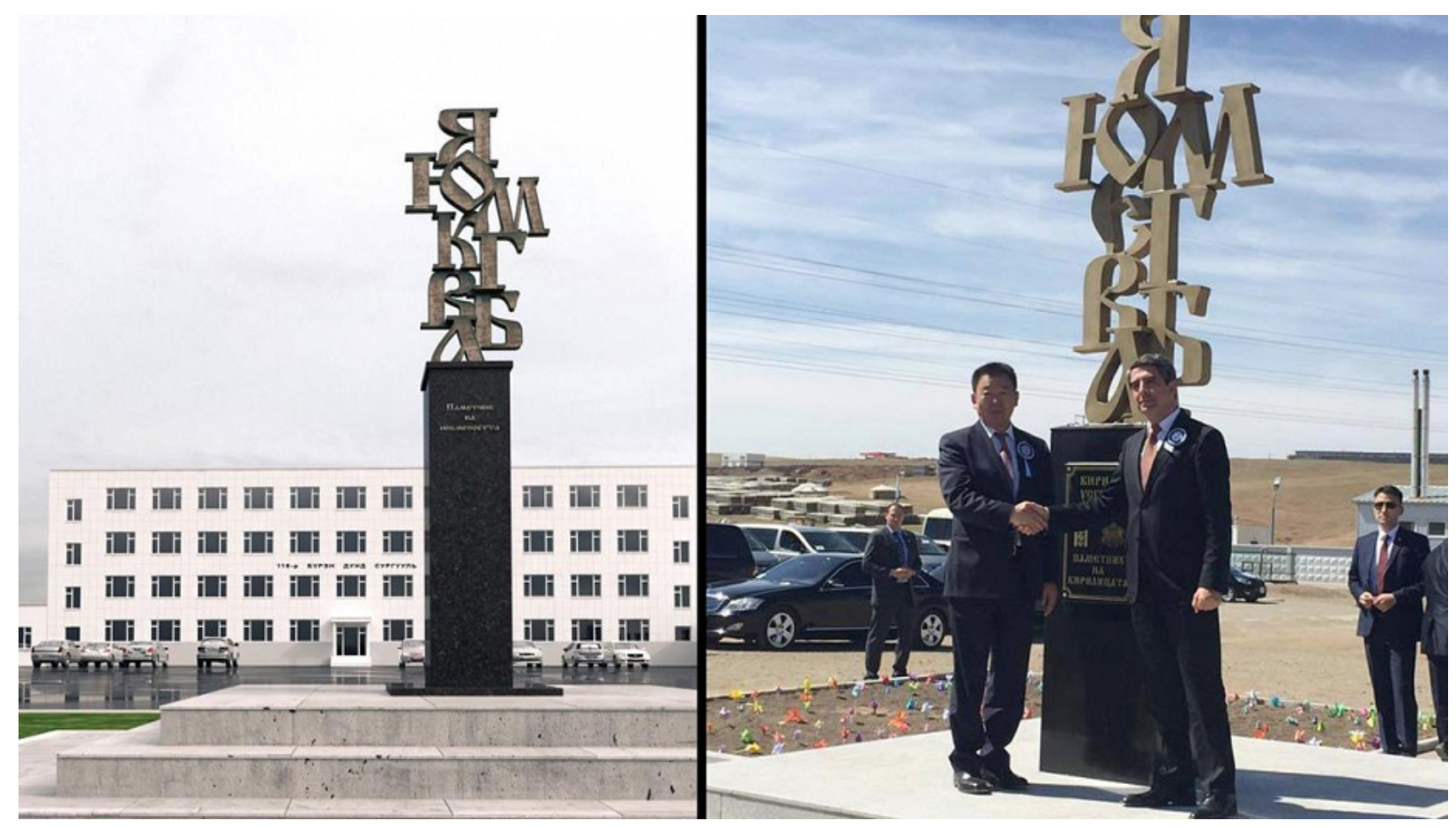

Foto 7: Ułan Bator. Autor: Spas Kirichev.

Źródło: https://kalinkamenov.com/2015/o5/mongolia-kirilica/ 


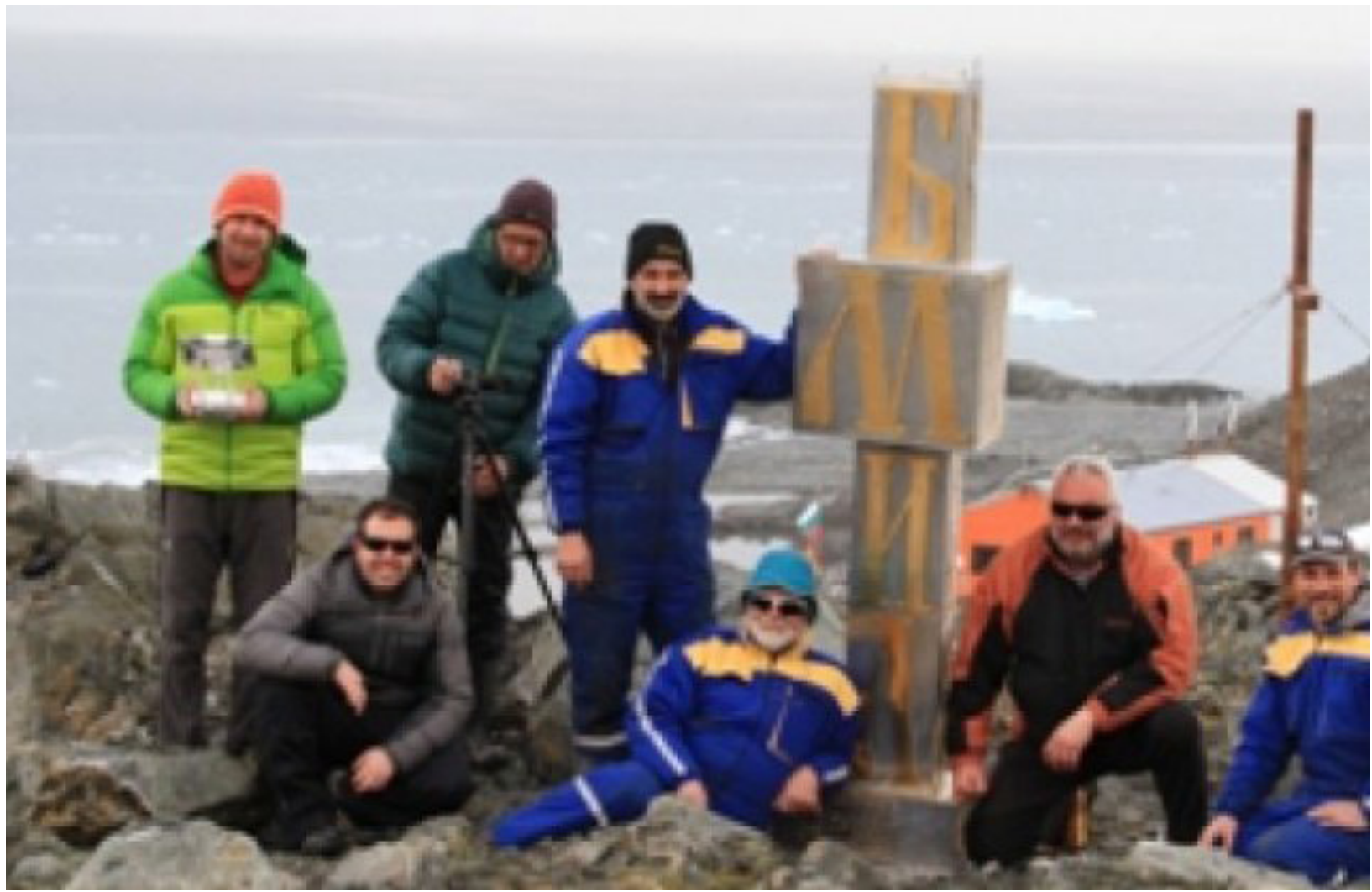

Foto 8: Pomnik cyrylicy na Antarktydzie. Autor: Mladen Jordanov Stanev.

Źródło: https://news.bg/society/veche-i-na-antarktida-ima-pametnik-na-kirilitsata.html

Wydarzenie to stało się okazją do podjęcia dalszej współpracy bułgarsko-mongolskiej w zakresie przygotowania kolejnego pomnika cyrylicy, który miał upamiętniać jubileusz 25-lecia Bułgarskiej ekspedycji na Antarktydzie. Odsłonięty na Biegunie Południowym w marcu 2018 roku, poświęcony wcześniej przez bułgarską Cerkiew, podobnie, jak podarowany Mongolii, powstał z dobrowolnych składek. U podstaw monumentu znalazły się hermetycznie zamknięte stalowe kapsuły z grudkami ziemi pochodzącymi z Pliski, Sofii, Warny, Weliko Tarnowo, miejscowości Weliki Preslaw i grobu Chana Kubrata na Ukrainie (News 2018).

Jak zapowiadano w bułgarskich mediach, jeszcze w roku 2018 miał stanąć w Rosji, w Nowosybirsku, kolejny pomnik alfabetu cyrylickiego. Jednak program obchodów święta Piśmiennictwa i Kultury Słowiańskiej w Nowosybirsku takiej uroczystości nie przewidywał. Kwestią dalszych badań pozostaje, na ile rozumienie tradycji słowiańskiej i dziedzictwa Cyryla i Metodego propagowanego przez Bułgarów, może oznaczać inny sens niż ten, który wpisywałby się w politykę prowadzoną w ramach programu Russkij Mir (Русский Мир).

Przegląd twórczości plastycznej związanej z Cyrylem i Metodym, choć nie obejmuje innych licznych dokonań artystycznych i ogranicza się tu do arbitralnego wyboru autorki, 
potwierdza rangę świętych Cyryla i Metodego w słowiańskim świecie. Wskazuje na ich wymiar religijny i wymiar bułgarskiej tradycji państwowej w pielęgnowaniu i podtrzymywaniu spuścizny Braci Sołuńskich. Z jednej strony potwierdza to odwoływanie się do ich dziedzictwa, jak było to jeszcze w XIX stuleciu, gdy w trosce o zachowanie swej tożsamości narodowej zaczęto przedstawiać ich w malarstwie, tworzyć pomniki, a powstającym stowarzyszeniom nadawać patronat tych świętych. Trwałość ich tradycji widoczna jest także współcześnie, co potwierdza sztuka oraz istniejące stowarzyszenia, które funkcjonują także w Polsce. Jednym z przykładów pozostaje działające od 30 lat Bractwo Prawosławne św. św. Cyryla i Metodego (Abijski \& Makal \& Wyspianski: 2019). Współczesny powrót do ich tradycji także wpisuje się we wspólnotowe działania Kościołów chrześcijańskich. Potwierdza to wypowiedź skierowana do Bułgarów w trakcie pielgrzymki do tego kraju papieża Franciszka. Zwracając uwagę na związki Apostołów Słowiańszczyzny z Bułgarią i ich misje szerzenia Ewangelii wśród Słowian, hierarcha przypomniał: Защото вашата земя е родина на свидетели на вярата, още от времето, когато светите братя Кирил и Методий са разпространявали там Евангелието (Rusenova 2019).

Przedstawione w artykule wizualne odniesienia do św. Cyryla i Metodego, poza religijnym wymiarem ich kultu w prawosławiu i katolicyzmie, wskazują, że Bułgarzy czyniąc się depozytariuszami ich dziedzictwa przywracają znaczenie alfabetu cyrylickiego. Kwestią wykraczającą poza ramy tego tekstu pozostaje odpowiedź na pytanie, na ile święci i strażnicy ich pamięci przyczyniają się do kształtowania pomostu pomiędzy dwiema różnymi tradycjami Kościelnymi.

\section{BIBLIOGRAFIA}

Abijski \& Makal \& Wyspianski 2o19: Abijski, Marcin \& Makal, Piotr \& Wyspianski, Slawek, eds. XXX Years Brotherhood of Saints Cyril and Methodius. Bialystok: Association of the Orthodox Brotherhood of Saints Cyril and Methodius, 2019. [In Polish: Abijski, Marcin \& Makal, Piotr \& Wyspiański, Sławek, red. XXX lat Bractwa Świętych Cyryla i Metodego. Białystok: Stowarzyszenie Bractwo Prawosławne św. św. Cyryla i Metodego, 2019.]

Antova 2018: Antova, Desislava. “Mission Bulgaria Headed for Beijing." News.bg, 29.03.2018, https://news.bg/bulgaria/misiya-balgariya-tragva-kam-pekin.html (Accessed 29.04.2019). [In Bulgarian: Антова, Десислава. „Мисия България тръгва към Пекин.” News.bg, 29.03.2018, https://news.bg/bulgaria/misiya-balgariya-tragva-kam-pekin.html. (Достъп 29.04.2019).]

Baniak 2004: Baniak, Jozef. "Inculturation." In: Gadacz, Tadeusz \& Milerski, Boguslaw, eds. Religion. PWN Encyclopedia. Vol. 5, 41. Warsaw: PWN, 2002. [In Polish: Baniak, Józef. 
„Inkulturacja.” W: Gadacz, Tadeusz \& Milerski, Bogusław, red. Religia. Encyklopedia PWN. T. 5, 41. Warszawa: PWN, 2002.]

Bartolini 1885: Bartolini, Domenico. "The Pilgrimage of Thanksgiving to the Holy Father Leo XIII, R.P. 1881”. In: Bartolini, Domenico. Historical, Critical and Archaeological Relics of Saints Cyril and Methodius and Their Apostolate in the Slavic Nations, V-XXIV. Poznan: Kuryer Poznanski, 1885. [In Polish: „Pielgrzymka dziękczynna wszechsłowiańska do Ojca świętego Leona XIII, R.P. 1881." W: Bartolini, Domenico. Pamiątki historyczne, krytyczne, archeologiczne świętych Cyryla i Metodego oraz apostolstwa ich śród narodów słowiańskich. Przekł. z włoskiego M. Chwaliszewski, V-XXIV. Poznań: Kuryer Poznański, 1885.]

Devetak 2016: Devetak, Jurij. The Parish of St. Cyril and Methodius in Belgrade and Lazarists. Beograd: Zupni ured sv. Cirila i Metodija, 2016. [In Croatian: Devetak, Jurij. Župa sv. Ćirila i Metodija u Beogradu i lazaristi. Beograd: Župni ured sv. Ćirila i Metodija, 2016.]

Dzhambazova 2013: Dzhambazova, Maya. "Monument of the Saints Brothers in Mongolia." Spisanie.to, 16.01.2013, https://www.spisanie.to/пътуване/история-и-цивилизация/паметникна-светите-братя-в-монголия/. [In Bulgarian: Джамбазова, Мая. „Паметник на светите братя в Монголия." Spisanie.to, 16.01.2013, https://www.spisanie.to/пътуване/история-ицивилизация/паметник-на-светите-братя-в-монголия/.]

Golabek 1935: Golabek, Jozef. Brotherhood of Saint. Cyril and Methodius in Kiev. Warsaw: Nasza Przyszlosc, 1935. [In Polish: Gołąbek, Józef. Bractwo św. Cyryla i Metodego w Kijowie. Warszawa: Nasza Przyszłość, 1935.]

Jarko 1991: Jarko, Jan. "Charismatic Ministry of the Apostles of the Slavs in the Light of the Old Slavic Literature.” In: Gajek, Jan Sergiusz \& Gorka, Leonard, eds. Cyril and Methodius Apostles and Slavic Teachers. Studies and Documents, Part 1, 99-107. Lublin: KUL, 1991. [In Polish: Jarko, Jan. „Charyzmatyczna posługa Apostołów Słowian w świetle piśmiennictwa starosłowiańskiego.” W: Gajek, Jan Sergiusz \& Górka, Leonard, red. Cyryl i Metody Apostołowie i Nauczyciele Stowian. Studia i dokumenty, cz. 1, 99-107. Lublin: KUL, 1991.]

Kamenov 2015: Kamenov, Kalin. "In Mongolia for a Feast of the Saints Brothers Cyril and Methodius". (Personal blog, published 11.05.2015). https://kalinkamenov.com/2015/05/mongolia-kirilica/. [In Bulgarian: Каменов, Калин. „В Монголия за празника на светите братя Кирил и Методий”. (Личен блог, публ. 11.05.2019). https://kalinkamenov.com/2015/05/mongolia-kirilica/.]

Krasteva 2oo6: Krasteva, Stefanka. "Slavic Cooperation and the Bulgarian Cultural and Historical Heritage.” Slavjanski glas, no. 1 (2006), 72-90. [In Bulgarian: Кръстева, Стефанка. „Славянското сътрудничество и българското културно-историческо наследство.” Славянски глас, по 1 (2006), 72-90.]

Mihajlova 2013: Mihajlova, Katja. "The Feast of St. Cyril and Methodius in Plovdiv - from Written to Family History." In: Atanasova, Ekaterina \& Lozanova, Galina \& Stanoev, Stanoj, eds. The Feast of St. Cyril and Methodius. Spaces of the Spirit. Vol. 2, 142-186. Sofia: Paradigma, 2014.

[In Bulgarian: Михайлова, Катя. „Празникът на св. Кирил и Методий в Пловдив - от писмена към семейна история." В: Анастасова, Екатерина \& Лозанова, Галина \& Станоев, Станой, ред. Празникът на свети Кирил и Методий. Пространства на духа. Т. 2, 142-186. София: Парадигма, 2013.] 
Moroz-Grzelak 2016: Moroz-Grzelak, Lilla. "The Slovenian Cult of Saint Cyril and Methodius Considering the Background of the Slavic Tradition." In: Boguslawska, Magdalena \& Goszczynska, Joanna \& Suler-Galos, Jasmina, eds. To Read, to Wander, to Be. A Volume Dedicated to Professor Zdzislaw Darasz, 59-72. Warsaw University Press, 2016. [In Polish: Moroz-Grzelak, Lilla. „Słoweński kult św. Cyryla i Metodego na tle tradycji ogólnosłowiańskiej." W: Bogusławska, Magdalena \& Goszczyńska, Joanna \& Šuler-Galos, Jasmina, red. Czytać, wędrować, być. Tom dedykowany Profesorowi Zdzisławowi Daraszowi, 59-72. Warszawa: Wydawnictwo UW, 2016.]

Moroz-Grzelak 2019: Moroz-Grzelak, Lilla. „The Patrons of the Slavic Nations of Europe. Cyril and Methodius in the Tradition of Orthodoxy and Catholicism." In: Korzeniewska-Wiszniewska, Mirella \& Kastory, Agnieszka \& Woznica, Rafal, eds. Central Europe and the Balkans. Historical and Political Science Contexts. Nations, National and Religious Minorities. Jubilee book dedicated to prof. dr hab. Irena Stawowy-Kawka, 331-342. Krakow: Jagiellonian University Press, 2019. [In Polish: Moroz-Grzelak, Lilla. „Patroni słowiańskich narodów Europy. Cyryl i Metody w tradycji prawosławia i katolicyzmu." W: Korzeniewska-Wiszniewska, Mirella \& Kastory, Agnieszka \& Woźnica, Rafał, red. Europa Środkowa i Bałkany. Konteksty historyczne i politologiczne. Narody, mniejszości narodowe i religijne. Księga jubileuszowa ofiarowana prof. dr hab. Irenie Stawowy-Kawce, 331-342. Kraków: Wydawnictwo UJ, 2019.]

Naumow 1999: Naumow, Aleksander. "The Kiev Tradition in Polish Orthodoxy." In: Lesniewski, Krzysztof \& Lesniewska, Jadwiga, eds. Orthodoxy - the Source of Faith and the Spring of Experience, 449-466. Lublin: Prawoslawna Diecezja Lubelsko-Chelmska, 1999. [In Polish: Naumow, Aleksander. „Tradycja kijowska w prawosławiu polskim.” W: Leśniewski, Krzysztof \& Leśniewska, Jadwiga, red. Prawosławie - źródto wiary i zdrój doświadczenia, 449-466. Lublin: Prawosławna Diecezja Lubelsko-Chełmska, 1999.]

Paisij 1981: Paisij Chilendarski. Slavo-Bulgarian History. Warsaw: Czytelnik, 1981. [In Polish: Paisij Chilendarski. Słowianobutgarska historia. Przekł. z bułgarskiego, wstęp, przypisy Franciszek Korwin-Szymanowski. Warszawa: Czytelnik 1981.]

Pavlov 2019: Pavlov, Plamen. "St. Methodius - Facts Unknown and Known. Chech Archaeologist Proves That the Archbishop's Burial Is in the Moravian Town of Mikulcice." Trud, 10.05.2019. https://trud.bg/свети-методий-неизвестното-в-известн/. [In Bulgarian: Павлов, Пламен. „Свети Методий - неизвестното и известното. Чешки археолог доказва, че гробът на архиепископа се намира в моравския град Микулчице.” Труд, 10.05.2019. https:/trud.bg/ свети-методий-неизвестното-в-известн/.]

Rusenova 2019: Rusenova, Violeta. "Pope Francis with an Address to Bulgarians." Vesti, 03.05.2019. https://www.vesti.bg/bulgaria/papa-francisk-s-obryshtenie-kym-bylgarite-6o9499o. [In Bulgarian: Русенова, Виолета. „Папа Франциск с обръщение към българите”, Vesti, 03.05.2019. https://www.vesti.bg/bulgaria/papa-francisk-s-obryshtenie-kym-bylgarite-6o9499o.]

Stojkova 2oo8: Stojkova, Ana. "The Bulgarian Medieval Cult of Cyril and Methodius: Ideological Parameters and Literary Reflections.” Slavia Meridionalis, no. 8 (2008): 309-326. [In Bulgarian: Стойкова, Ана. „Култ към св. Кирил и Методий през Българското средновековие. Идеологически параметри и литературни рефлекси." Slavia Meridionalis, no. 8 (2008): 309-326.] 
Vrabchev 2015: Vrabchev, Andrey. "We Don't Know What Bulgarianness Is at the Moment." Interview by Ana Kocheva. Frognews, 7.09.2015. https://frognews.bg/inteviu/skulptorat-vrabchevznaem-kakvo-balgarshtinata-momenta.html. [In Bulgarian: Врабчев, Андрей. „Не знаем какво е българщината в момента." Интервю на Ана Кочева. Frognews, 7.09.2015. https://frognews.bg/ inteviu/skulptorat-vrabchev-znaem-kakvo-balgarshtinata-momenta.html.]

Wojtczak 2004: Wojtczak, Marcin. "Saints Cyril and Methodius in Bulgarian Slavophilism." In: Mikolajczak, Aleksander W. \& Szulc, Witold \& Zielinski, Boguslaw eds. Community Ideas of Slavdom, 259-266. Poznan: 259-266. [In Polish: Wojtczak, Marcin. „Święci Cyryl i Metody w słowianofilstwie bułgarskim.” W: Mikołajczak, Aleksander W. \& Szulc, Witold \& Zieliński, Bogusław, red. Idee wspólnotowe Słowiańszczyzny, 259-266. Poznań: Wydawnictwo Naukowe UAM, 2004.] 